\title{
Cell-Wall Deficiencies in L-forms of Staphylococcus aureus
}

\author{
By B. C. PRATT* \\ Department of Bacteriology, Wright-Fleming Institute of Microbiology, \\ St Mary's Hospital Medical School, London, W.2
}

(Received 3 August 1965)

\begin{abstract}
SUMMARY
Three strains of penicillin-induced and one strain of D-cycloserineinduced L-forms of Staphylococcus aureus were investigated for components of the normal bacterial cell wall. None of the 4 strains was found to contain more than $0.008 \%$ of its dry weight as muramic acid, indicating the lack of mucopeptide. These forms also lacked the cell-wall ribitol teichoic acid as shown by the failure to yield any material containing ribitol. Neither muramic acid nor ribitol was detected as acid-soluble nucleotides in the L-forms, and teichoic acid was not released into the supernatant medium. Serological evidence for polysaccharide A was not found, but there was serological identity between extracts of membranes obtained from staphylococci and extracts of membranes isolated from the L-forms.
\end{abstract}

\section{INTRODUCTION}

Since the report of Dienes \& Sharp (1956) on the isolation of various organisms in the L-phase by using a medium containing a high salt concentration, serum and penicillin, there have been several studies on the biology of the L-forms, including those of Staphylococcus aureus (Schönfeld, 1959, 1961; Marston, 1961 $a, b$; Williams, 1963). Although these reports, particularly the last, gave indirect evidence, such as osmotic fragility, phage and antibiotic insensitivity, for the lack of cell-wall material, no direct evidence was presented. Only one report has appeared on cell-wall components of staphylococcal L-forms; Sharp (1963) found a very low level of muramic acid in an L-form from staphylococcus $\mathrm{H}$.

The mucopeptide of the cell wall has been shown to be absent or greatly decreased in amount both in streptococcal L-forms (Panos, Barkulis \& Hayashi, 1959) and stable Proteus L-forms (Kandler, Hund \& Zehender, 1958; Morrison \& Weibull, 1962), and in the doubtfully related Mycoplasma group (Plackett, 1959). Further evidence for a deficiency in cell-wall components from L-forms has been provided by serological techniques; for example, the L-forms of group A streptococci were found to lack group-specific polysaccharide (Sharp, Hijmans \& Dienes, 1957). Similar results had earlier been obtained in the cases of L-forms of Streptobacillus moniliformis (Klieneberger, 1942) and Proteus (Dienes, Weinberger \& Madoff, 1950), although these studies antedated much important work on cell-wall structures. The present paper reports some attempts to demonstrate cell-wall components in L-forms of Staphylococcus aureus.

* Present address : Chemistry Department, University College, Swansea. 


\section{METHODS}

Organisms and media. Three strains of staphylococcal L-form, 1444L, 6L and $42 \mathrm{E}$, previously described by Williams (1963), were used. A fourth strain, $\mathrm{L}$ Rogers, isolated from a penicillinase-producing staphylococcus (phage type 42 E) by growth in the presence of $\mathrm{D}$-cycloserine, was also used.

The solid and liquid media used for growth of the penicillin-induced L-forms were those described by Williams (1963). The media used for L Rogers were essentially the same except that more sodium chloride was added to give a final concentration of $4.5 \%(\mathrm{w} / \mathrm{v})$ and the penicillin was replaced by $\mathrm{D}$-cycloserine (Lilly) $500 \mu \mathrm{g} . / \mathrm{ml}$.

Broth cultures of the L-forms were harvested after $48 \mathrm{hr}$ incubation at $37^{\circ}$ by centrifugation at $27,000 \mathrm{~g}$ for $10 \mathrm{~min}$. The pellet was washed once with ice-cold salt solution of the appropriate strength and then extracted by grinding for $\mathbf{5} \mathrm{min}$. with cold $10 \%(\mathrm{w} / \mathrm{v})$ trichloroacetic acid (TCA). The residue was recovered by centrifugation and dialysed in the cold overnight against distilled water and lyophilized.

The parent staphylococci were grown in Difco brain heart infusion broth overnight at $37^{\circ}$, centrifuged, washed once with physiological saline, once with distilled water and either lyophilized or used directly for the preparation of cell walls.

Preparation of cell fractions. Cell walls of the parent staphylococci were isolated by the method of Salton \& Horne (1951), by using a Mickle tissue disintegrator and no. 12 ballotini beads.

Staphylococcal cell membranes and membranes from the L-form strains were isolated essentially as described by Freimer (1963) for similar structures from group A streptococci and osmotically fragile protoplasts. The supernatant fluids remaining after removal of cell walls and membranes from suspensions of disrupted staphylococci (or membranes from suspensions of lysed L-forms) were centrifuged at $100,000 \mathrm{~g}$ for $1 \mathrm{hr}$ and the resulting 'ribosomal' gel (Davison \& Baddiley, 1963) was lyophilized.

Mucopeptide fractions from whole staphylococci were isolated by the method of Park \& Hancock (1960) and by extraction with hot formamide (Fuller, 1938). Whole L-form was also extracted using these methods and the resulting residues lyophilized.

Attempts to isolate teichoic acids from staphylococci and L-forms were made by extraction with cold $10 \%$ (w/v) TCA (Armstrong et al. 1958).

Paper chromatography. Samples for the chromatographic detection of amino acids and amino sugars were hydrolysed in $4 \mathrm{~N}-\mathrm{HCl}$ at $100^{\circ}$ for $16 \mathrm{hr}$ in sealed tubes. The compounds were separated on Whatman no. 1 paper by an ascending twodimensional technique using the solvents: (a) $n$-butanol+acetic acid + water $(120+30+50$, by vol.); (b) 2, 4/2, 5 lutidine + water $(130+70$, by vol. $)$.

The dried papers were dipped in ninhydrin reagent $(0 \cdot 2 \%(\mathrm{w} / \mathrm{v})$ in acetone) and heated for $5 \mathrm{~min}$. at $90^{\circ}$. Sugar alcohols were released by hydrolysis in $2 \mathrm{~N}-\mathrm{HCl}$ at $100^{\circ}$ for $3 \mathrm{hr}$ and were separated by descending chromatography on Whatman no. 1 paper with solvent $n$-butanol + acetic acid + water $(120+30+50$, by vol.) Periodic acid + benzidine reagent (Smith, 1960) was used to detect the sugar alcohols. 
Hexosamines. Hydrolysis of samples for the quantitative estimation of hexosamines was done in $4 \mathrm{~N}-\mathrm{HCl}$ at $100^{\circ}$ for $4 \mathrm{hr}$. The hydrolysates were freed from interfering chromogens according to Boas (1953) and the total hexosamine content estimated by the method of Rondle \& Morgan (1955). Colours were read at $530 \mathrm{~m} \mu$ in a $1 \mathrm{~cm}$. optical cell and compared with a glucosamine standard.

The individual amino sugars were separated on charcoal + celite columns (Perkins \& Rogers, 1959) and muramic acid estimated by a micro modification of the Rondle \& Morgan test. The reagents used in the micro modification were those described for the original test, but the final test volume was only $1.5 \mathrm{ml}$. instead of $10 \mathrm{ml}$. Extinctions were read at a wavelength of $505 \mathrm{~m} \mu$ in a $2 \mathrm{~cm}$. micro-cell after $24 \mathrm{hr}$ and compared with a standard of authentic muramic acid (kindly supplied by Dr H. R. Perkins).

Agar-gel diffusion. Tests were made in a gel consisting of $1 \%(w / v)$ Ionagar no. 2 (Oxoid) in $\mathrm{m} / 30$ phosphate buffer ( $\mathrm{pH}$ 7.2). Antigen preparations were suspended or dissolved in the same buffer. Antisera to staphylococci and L-forms were prepared in rabbits by a series of intravenous injections of whole organisms.

\section{RESULTS}

\section{Hexosamines}

Preliminary chromatographic evidence suggested that the amino sugar content of the L-forms was very much less than that of the parent staphylococci. In none of the four L-form strains was either muramic acid or glucosamine detected chromatographically, even when large (up to $10 \mathrm{mg}$.) samples of starting material were used. Large samples of L-form, which had not been extracted with cold $10 \%$ TCA prior to drying, yielded on hydrolysis and chromatography a minute quantity of a substance corresponding in $\boldsymbol{R}_{F}$ values to glucosamine. On acidwashing of the harvested L-form, however, this chromatographic spot was not detectable.

Separation of the total hexosamines from hydrolysates and quantitative estimation confirmed the results obtained by chromatography. Whereas the total hexosamine separated from hydrolysates of bacterial cells accounted for $2 \cdot 79-3 \cdot 8 \%$ of the dry weight of the organism, in hydrolysates of L-forms the amino sugars were not present in sufficient quantity to allow estimation. Consequently, the lower level of sensitivity of the test was taken as the maximum possible amino sugar content (Table 1).

\section{Estimation of muramic acid content}

The results above give total hexosamine content, but for the purposes of this investigation, estimation of the muramic acid content was of prime importance. Hydrolysates of both cocci and L-forms were treated on charcoal + Celite columns and the eluates that could be expected to contain muramic acid were collected. Estimation of the muramic acid contents of the eluates from L-forms gave very low values in the conventional Rondle \& Morgan test, with glucosamine as a standard. Greater sensitivity was gained, however, by using the micro modification of the Rondle \& Morgan test and by using authentic muramic acid as standard. In an effort to concentrate muramic acid further, the fractions of whole organisms, 
Table 1. Total hexosamine content of staphylococci and L-forms

\begin{tabular}{|c|c|c|c|}
\hline & $\begin{array}{c}\text { Sample } \\
\text { (mg.) }\end{array}$ & $\begin{array}{l}\text { Hexosamine* } \\
\text { content ( } \mu \mathrm{g} .)\end{array}$ & $\begin{array}{c}\text { Hexosamine as } \\
\% \text { dry weight }\end{array}$ \\
\hline $\begin{array}{r}\text { 1444 cocci } \\
\text { L-form } \begin{array}{r}1 \\
2\end{array}\end{array}$ & $\begin{array}{l}10 \cdot 18 \\
12 \cdot 20 \\
26 \cdot 50\end{array}$ & $\begin{array}{l}284 \\
<10 \\
<10\end{array}$ & $\begin{array}{c}\mathbf{2 . 7 9} \\
<\mathbf{0 . 0 8 2} \\
<0.038\end{array}$ \\
\hline 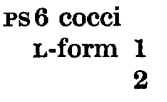 & $\begin{array}{r}10 \cdot 62 \\
7 \cdot 10 \\
31 \cdot 20\end{array}$ & $\begin{array}{l}309 \\
<10 \\
<10\end{array}$ & $\begin{array}{c}2.91 \\
<0.141 \\
<0.032\end{array}$ \\
\hline $\begin{array}{r}\text { PS 42 E cocci } \\
\text { L-form } \begin{array}{r}1 \\
2\end{array}\end{array}$ & $\begin{array}{r}9 \cdot 65 \\
6 \cdot 70 \\
28 \cdot 80\end{array}$ & $\begin{array}{l}279 \\
<10 \\
<10\end{array}$ & $\begin{array}{c}2.89 \\
<0.149 \\
<0.035\end{array}$ \\
\hline $\begin{array}{c}\text { Rogers cocci } \\
\text { L-form } 1 \\
2\end{array}$ & $\begin{array}{r}2 \cdot 50 \\
6 \cdot 70 \\
12 \cdot 50\end{array}$ & $\begin{array}{r}95 \\
<10 \\
<10\end{array}$ & $\begin{array}{c}3 \cdot 80 \\
<0 \cdot 149 \\
<0.080\end{array}$ \\
\hline
\end{tabular}

* Material eluted by $2 \mathrm{~N}-\mathrm{HCl}$ from Dowex $50 \mathrm{H}^{+}$, estimated in Rondle \& Morgan (1955) test at $530 \mathrm{~m} \mu$ and expressed as glucosamine base.

Table 2. Muramic acid contents of isolated fractions from whole staphylococci and $L$-forms

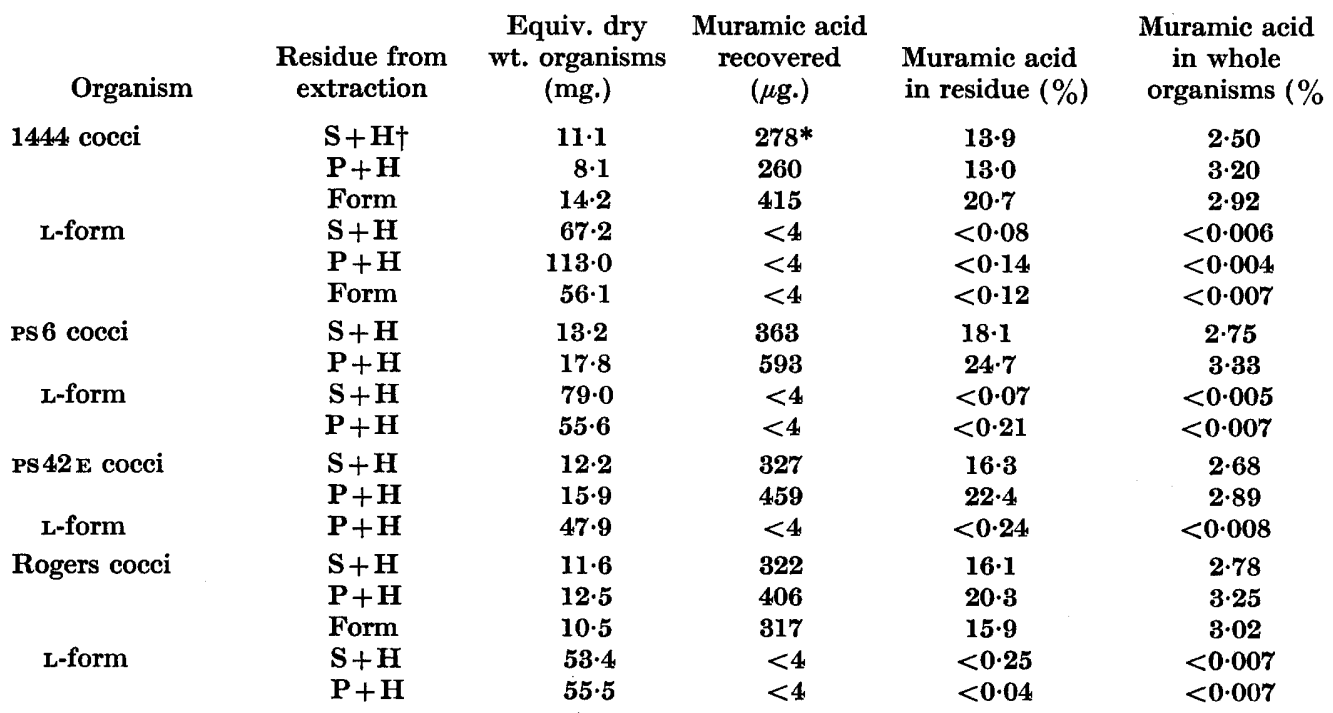

* Extraction methods used: Salton \& Horne (1951), S+H; Park \& Hancock (1960), P+H; Fuller (1938), Form.

$\dagger$ Estimated using the micro modification of Rondle \& Morgan (1955) method; expressed in terms of a muramic acid standard.

whether cocci or L-forms, likely to contain the amino sugar were isolated. Hydrolysis of these fractions and estimation of their muramic acid contents gave the results shown in Table 2.

Since the results shown in Table 2 were obtained with preparations of L-forms which had been extracted with $10 \%(\mathrm{w} / \mathrm{v})$ TCA, there remained the possibility that 
the L-forms might have contained small amounts of muramic acid in an acidsoluble form. Trichloroacetic acid was removed from the extracts with ether, and the aqueous solutions dried. Hydrolysis of the acid-soluble material and subsequent amino sugar estimation yielded no evidence of muramic acid.

Although the level of estimation of muramic acid was considerably decreased by using the micro modification, no detectable colour at $505 \mathrm{~m} \mu$ was found in hydrolysates of fractions from L-forms. The maximum amount of muramic acid which could be present was taken as $4 \mu \mathrm{g}$. By virtue of the characteristic spectrum of muramic acid in this test, lower values than $4 \mu \mathrm{g}$. were detectable but could not be measured with certainty. Even so, the results obtained serve to show the absence of muramic acid and so of cell-wall mucopeptide from the L-forms of Staphylococcus aureus.

\section{Cell-wall teichoic acid}

The loss of mucopeptide during induction to the L-phase raises the question of the fate of the other major cell-wall polymer, the ribitol teichoic acid. If it were still produced, this teichoic acid could be found in two possible sites, still attached to the cell even in the absence of rigid mucopeptide, or it could be released into the medium as produced. Whole L-form preparations were hydrolysed to release any sugar alcohols that they might contain and the hydrolysates subjected to paper chromatography. At the same time, samples of whole cocci were similarly treated. Staining of the developed chromatograms with the periodic acid+benzidine reagent revealed the presence of spots corresponding to ribitol and anhydroribitol in hydrolysates of cocci. Small amounts of glycerol were also detected. Faint traces of glycerol but no spots corresponding to ribitol or anhydroribitol were evident in hydrolysates of L-forms.

Prolonged extraction of samples of L-forms with cold $10 \%(w / v)$ TCA, the normal procedure for extraction of teichoic acids, did not remove any material containing either ribitol or glycerol. The same treatment, when applied to the parent staphylococci, extracted an ethanol-insoluble substance, which on hydrolysis and chromatography yielded spots characteristic of both ribitol- and glycerolteichoic acids.

Hydrolysates of freeze-dried supernatant medium from L-form cultures contained no detectable ribitol or anhydroribitol, but did contain traces of glycerol. In spite of this finding, prolonged extraction of the broth residue with cold TCA and attempts to precipitate glycerol teichoic acid proved fruitless.

\section{Agar-gel diffusion}

Further evidence for the lack of ribitol teichoic acid from the L-form strains was provided by gel diffusion experiments. Whereas suspensions of whole staphylococci or cell walls produced a characteristic 'polysaccharide A' precipitation line when diffused against antiserum to Staphylococcus aureus, suspensions of the L-forms did not. No 'polysaccharide $A$ ' was extracted from any of the L-form strains by the technique of Haukenes, Losnegard \& Oeding (1961). The L-forms produced only what appeared to be a single line with the staphylococcal antiserum; and this line showed identity with one produced by intracellular contents isolated from the staphylococci. 
Since the normal cell wall of the coccus had been so drastically altered during induction to the L-form, the normal means of serological identification were lost. However, trypsin extracts of membranes isolated from the four L-form strains, when diffused against L-form antiserum produced apparently single precipitation lines (Fig. 1). These lines showed fusion with each other, indicating the serological identity of the original membranes. Similar preparations of $42 \mathrm{E}$ staphylococcal cell membranes also produced a single precipitation line with L-form antiserum. Fusion of this line with that produced by a trypsin preparation of $42 \mathrm{E}$ L-form membranes (Fig. 2) established the similarity between the membrane structures of the staphylococcus and its L-form. This relationship held for all four strains of staphylococci and L-forms, and cross-reaction between the strains was complete.

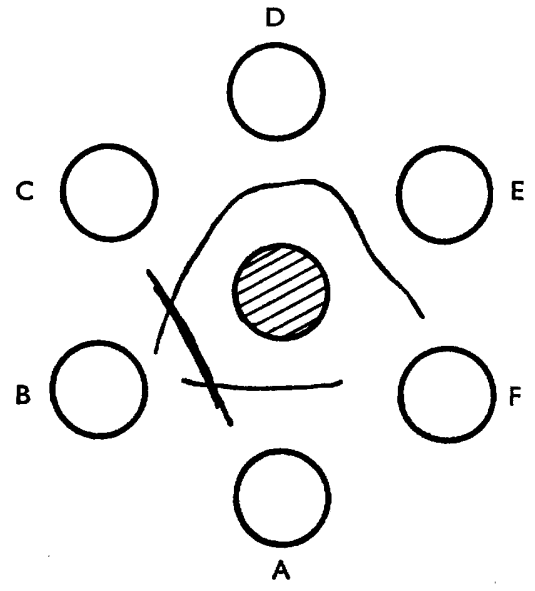

Fig. 1

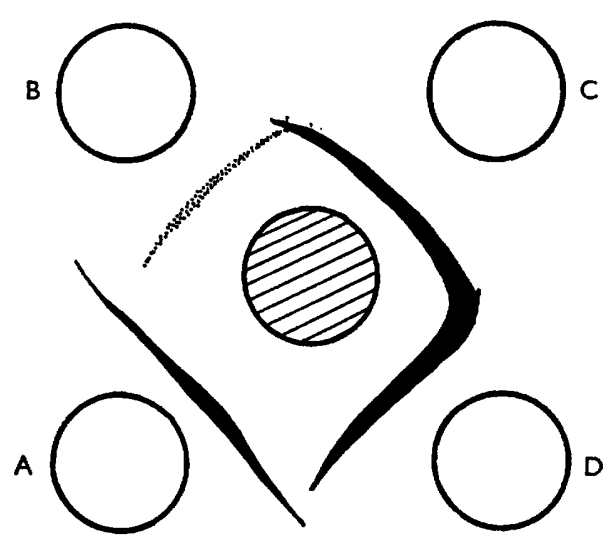

Fig. 2

Fig. 1. Agar-gel precipitin reactions of 1444 L-form antiserum (centre well) with trypsin extracts of membranes isolated from (A) 1444L, (C) 42 EL, (D) $6 \mathrm{~L}$ and (E) L Rogers. Well B contains a buffer suspension of whole $1444 \mathrm{~L}$-form and $\mathrm{F}$ a trypsinbuffer control.

Fig. 2. Precipitin reactions of $42 \mathrm{E}$ L-form antiserum (centre well) with (A) whole 42 E L-form, (B) trypsin extract of $42 \mathrm{E}$ cell walls, (C) trypsin extract of $42 \mathrm{E}$ staphylococcal cell membranes and (D) trypsin extract of 42E L-form membranes.

\section{DISCUSSION}

The nature of the change produced in the cell wall of Staphylococcus aureus during induction to the $\mathrm{L}$-form was indicated by Williams (1963), who described the osmotic sensitivity and insusceptibility to phage action in the staphylococcal L-form. These characters, together with the evidence of antibiotic sensitivities, presented in the same paper, pointed to an alteration in surface structure in the L-form, but did not of themselves provide proof of total lack of cell wall material. Sharp (1963) presented evidence for the absence of muramic acid from one strain of staphylococcal L-form, that of $S$. aureus $\mathrm{H}$. The results of the chemical analyses for muramic acid content of the four staphylococcal $L$-forms agree with the findings reported by Sharp. However, a further indication of the extensive loss of cellwall material from the $\mathrm{L}$-forms is evident from the failure to find ribitol teichoic 
acid in these organisms. Since the precise structural relationship between the cell-wall teichoic acid and the muramic-acid-containing mucopeptide is unknown, it is impossible to judge whether the non-production of ribitol teichoic acid might be caused by the absence of rigid mucopeptide or is a more direct consequence of antibiotic action.

In L-forms of group A streptococci, the $M$ protein, which is normally found in the cell wall, is still produced but is liberated into the culture medium (Sharp, Hijmans \& Dienes, 1957). The possibility was considered that the teichoic acid of the staphylococci might behave in the same way but no evidence for this was found.

With the absence of cell wall and the loss of characters such as cell-wallassociated antigens, Gram-staining properties and typical morphology, the identification of the L-forms as being derived from Staphylococcus aureus is difficult. Williams (1963) described the continued coagulase production by, and lysogenicity of, the L-forms. The present finding that the surface membrane of the L-form bears a close serological relationship to the cell membrane of the staphylococcus provides additional evidence on the origin of the L-form strains.

The author gratefully acknowledges the technical assistance of Miss J. Corse during this investigation. The work was supported by a grant from Pfizer Ltd.

\section{REFERENCES}

Armstrong, J. J., Badpiley, J., Buchanan, J. G., Carss, B. \& Greenberg, G. R. (1958). Isolation and structure of ribitol phosphate derivatives (teichoic acids) from bacterial walls. J. chem. Soc. p. 4344 .

BoAs, N. F. (1953). Method for the determination of hexosamines in tissues. $J$. biol. Chem. 204, 553.

Davison, A. L. \& Baddiley, J. (1963). The distribution of teichoic acids in staphylococci. J. gen. Microbiol. 32, 271.

Dienes, L. \& Sharp, J. T. (1956). The role of high electrolyte concentration in the production and growth of L-forms of bacteria. J. Bact. 71, 208.

Dienes, L., Weinberger, H. J. \& MAdoff, S. (1950). Serological reactions of L-type cultures isolated from Proteus. Proc. Soc. exp. Biol. Med. 75, 409.

Frermer, E. H. (1963). Studies of L-forms and protoplasts of group A streptococci. II. Chemical and immunological properties of the cell membrane. J. exp. Med. 117, 377 .

Fuller, A. T. (1938). The formamide method for the extraction of polysaccharides from haemolytic streptococci. Br. J. exp. Path. 19, 130.

Haukenes, G., Losnegard, N. \& Oeding, P. (1961). Extraction and fractionation of antigenic material from Staphylococcus aureus. Acta path. microbiol. scand. 53, 84.

KaNDLER, O., Hund, A. \& ZeHENDER, C. (1958). Cell wall composition in bacterial and L-forms of Proteus vulgaris. Nature, Lond. 181, 572.

KuIENEBErger, E. (1942). Some new observations bearing on the nature of the pleuropneumonia-like organism known as L1 associated with Streptobacillus moniliformis. J. Hyg., Camb. 42, 485.

MARSTON, J. (1961 a). Observations on L-forms of staphylococci. J. infect. Dis. 108, 75.

Marston, J. $(1961 b)$. Cultivation of staphylococcal L-forms in a liquid medium. J. Bact. 81, 832.

Morrison, T. H. \& Weibull, C. (1962). The occurrence of cell wall constituents in stable Proteus L-forms. Acta path. microbiol. scand. 55, 475.

Panos, C., Barkulis, S. S. \& Hayashi, J. A. (1959). Streptococcal L-forms. II. Chemical composition. J. Bact. 78, 863. 
Park, J. T. \& Hancock, R. (1960). A fractionation procedure for studies of the synthesis of cell-wall mucopeptide and of other polymers in cells of Staphylococcus aureus. J. gen. Microbiol. 22, 249.

Perkins, H. R. \& Rogers, H. J. (1959). The products of the partial acid hydrolysis of the mucopeptide from cell walls of Micrococcus lysodeikticus. Biochem. J. 72, 647 .

Plackett, P. (1959). On the probable absence of 'mucocomplex' from Mycoplasma mycoides. Biochim. biophys. Acta, 35, 260.

Rondle, C. J. M. \& Morgan, W. T. J. (1955). The determination of glucosamine and galactosamine. Biochem. J. 61, 586.

Salton, M. R. J. \& HoRne, R. W. (1951). Bacterial cell wall. II. Methods of preparation and some properties. Biochim. biophys. Acta, 45, 355.

SCHÖNFELD, J. K. (1959). ' $L$ '-Forms of staphylococci; their reversibility; changes in the sensitivity pattern after several intermediary passages in the ' $L$ ' phase. Antonie van Leeurvenhoek, 25, 325.

SchöNFELd, J. K. (1961). 'L'-Forms of Staphylococcus. II. Studies on the morphology of the transformation and on the reversibility. Antonie van Leeuwenhoek, 27, 139.

Sharp, J. T. (1963). Amino sugars in L-forms of bacteria and pleuropneumonia-like organisms. J. Bact. 86, 692.

Sharp, J. T., HiJmans, W. \& Dienes, L. (1957). Examination of the L-forms of group A streptococci for the group-specific polysaccharide and M protein. J.exp. Med. 105, 153.

SмIтн, I. (1960). Chromatographic Techniques, Vol. I. London: Heinemann.

Williams, R. E. O. (1963). L-forms of Staphylococcus aureus. J. gen. Microbiol. 33, 325. 